\title{
New chromosome numbers reported in grasses from Himachal Pradesh (India)
}

\author{
Harpreet Kaur, Santosh Kumari and Raghbir Chand Gupta ${ }^{1}$ \\ Department of Botany, Punjabi University, Patiala 147 002, India \\ ${ }^{1}$ Author for correspondence: guptarc53@rediffmail.com \\ Received January 16, 2011; accepted February 17, 2011
}

\begin{abstract}
At present, cytological evaluation has been done on population basis of nine species belonging to six genera of family Poaceae from district Kangra of Himachal Pradesh, a hilly state of Western Himalayas. On the basis of world-wide data, the chromosome number counts have been made for the first time for three species such as Agrostis debilis ( $n=14)$, Poa nepalensis $(n=14)$ and $P$. setulosa $(n=14)$; variable chromosome number reports for Eleusine indica $(n=14)$ and higher frequency of B-chromosomes in Poa annua $(n=14+0-3 B)$. Likewise, for information on reports from India, four species such as Piptatherum microcarpum $(n=12)$, Rottboellia exaltata $(n=30)$, Setaria barbata $(n=18)$ and Setaria megaphylla $(n=18)$ have been cytologically worked out for the first time.
\end{abstract}

KEYWORDS: Chromosome number counts, Himachal Pradesh, Variable chromosome numbers, Western Himalayas.

Himalayas is megacentre of biodiversity and approximately 2,532 endemic plant species are present in this part of India. Western part of Himalayas itself makes rich phytogeographical area of Northern India with diverse climatic zones ranging from lower subtropical foothills upto high altitude temperate zone with extremity ending in the alpine form. As a part of our continued research programme to evaluate genetic diversity of angiospermic flora of Western Himalayas through population based cytotaxonomical studies, the present work has been done on more than 120 species belonging to Monocotyledonous group alone, from district Kangra of Himachal Pradesh, a hilly state of Western Himalayas. On the basis of detailed cytomorphological studies as well as perusal of literature, some interesting results are scored for grass species as per details given in this paper.

\section{Materials and Methods}

Materials for the meiotic studies were collected from different localities of district Kangra (Table I). Voucher specimens were deposited in the Herbarium, Department of Botany, Punjabi University, Patiala (PUN). Meiotic studies were carried out through standard smearing technique from young panicles fixed in Carnoy's fixative. Photomicrographs of chromosome counts were made from freshly prepared slides using Nikon 80i eclipse Digital Imaging System.

\section{Results and Discussion}

The information about specific locality with altitude, present chromosome number in the light of previous reports along with comments on exact cytological evaluation of each species is provided in Table 1.

1) Agrostis debilis (Hook.f.) Bor = Calamagrostis debilis Hook.f.

The genus is constituted of about 200 species (Airy Shaw
1973) out of which 28 species are reported from Indian subcontinent (Bor 1960). At present, the species is found to be common along water springs at Bhagsunaag between altitudes of 1,000-1,800 m. It is characterized by lemma with long bearded callus; anthers small, $0.5 \mathrm{~mm}$ long; spikelets $4-5 \mathrm{~mm}$ long and awn dorsal in position. The flowering and fruiting is seen in the months of JulySeptember. The course of meiosis is noted to be normal with $n=14$ (Fig. 1).

\section{2) Eleusine indica (L.) Gaertner}

The genus comprises of nine tropical and subtropical species in the world (Airy Shaw 1973) including three species from Indian subcontinent (Bor 1960). The presently worked out species is found mostly in open wastelands, along roadsides and as a weed in cultivated fields in altitudinal range of 300-1,500 m in Himachal Pradesh. The species is annual with spikes slender, narrow, straight and nearly glabrous at the base. The flowering and fruiting occurs in the months of June-September. The course of meiosis is found to be normal with $n=14$ (Fig. 2).

\section{3) Piptatherum microcarpum (Pilg.) Tzvelev = Oryzopsis microcarpa Pilg.}

The genus is represented by 50 species in the world covering 11 species from India (Santapau and Henry 1973). The worked out species is characterized by glumes 6-7.5 mm long; lemma glabrous, broadly elliptic acute, 2.5-3 mm long, shining brown and fruit about half the length of the glumes. It is found mostly at shady and moist places in altitudes ranging from $1,000-2,500 \mathrm{~m}$ in Himachal Pradesh. The flowering and fruiting occurs in the months of June-September. The course of meiosis is found to be normal with $n=12$ (Fig. 3).

4) Poa annua $L$.

The genus comprises of 300 cosmopolitan species (Airy 


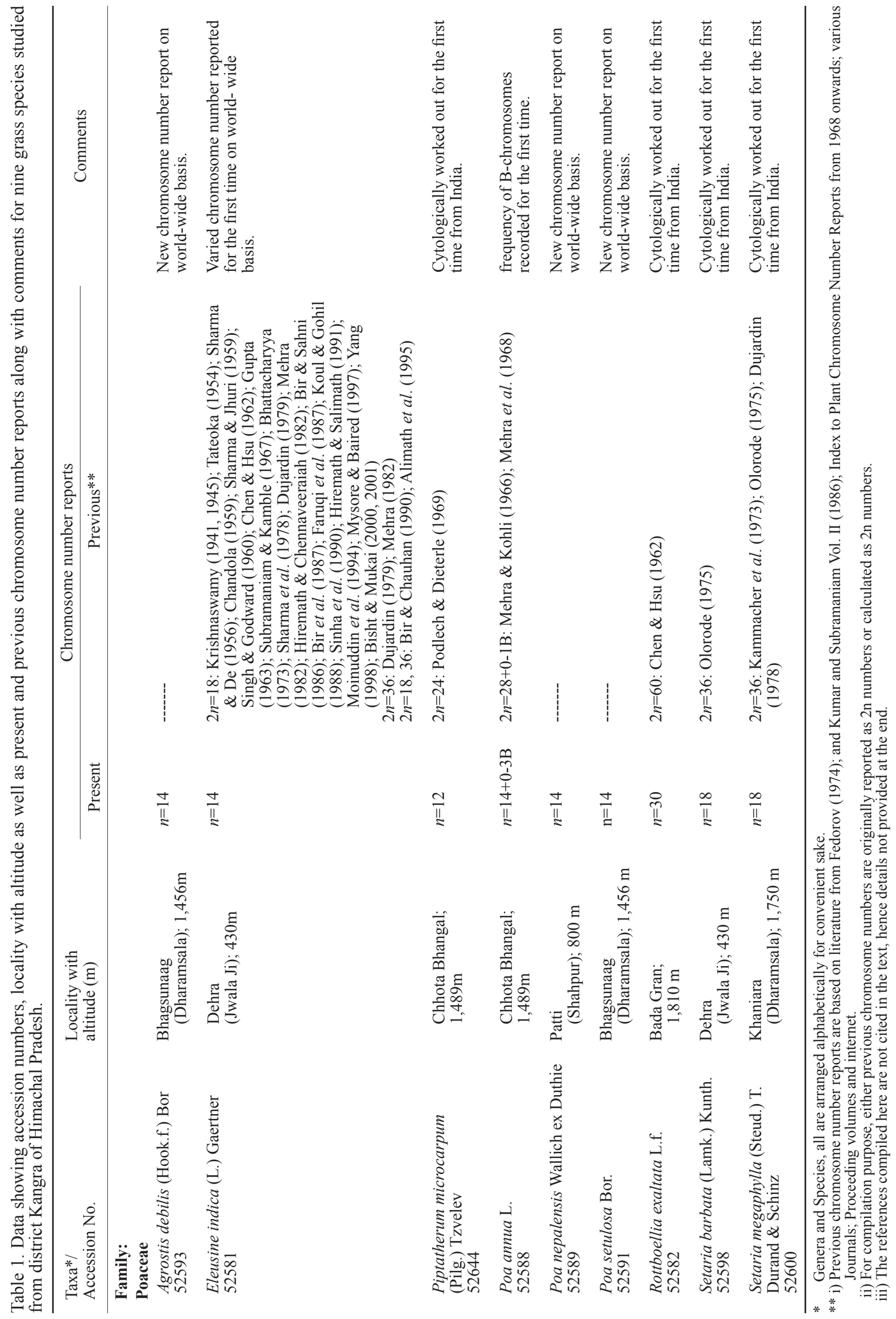



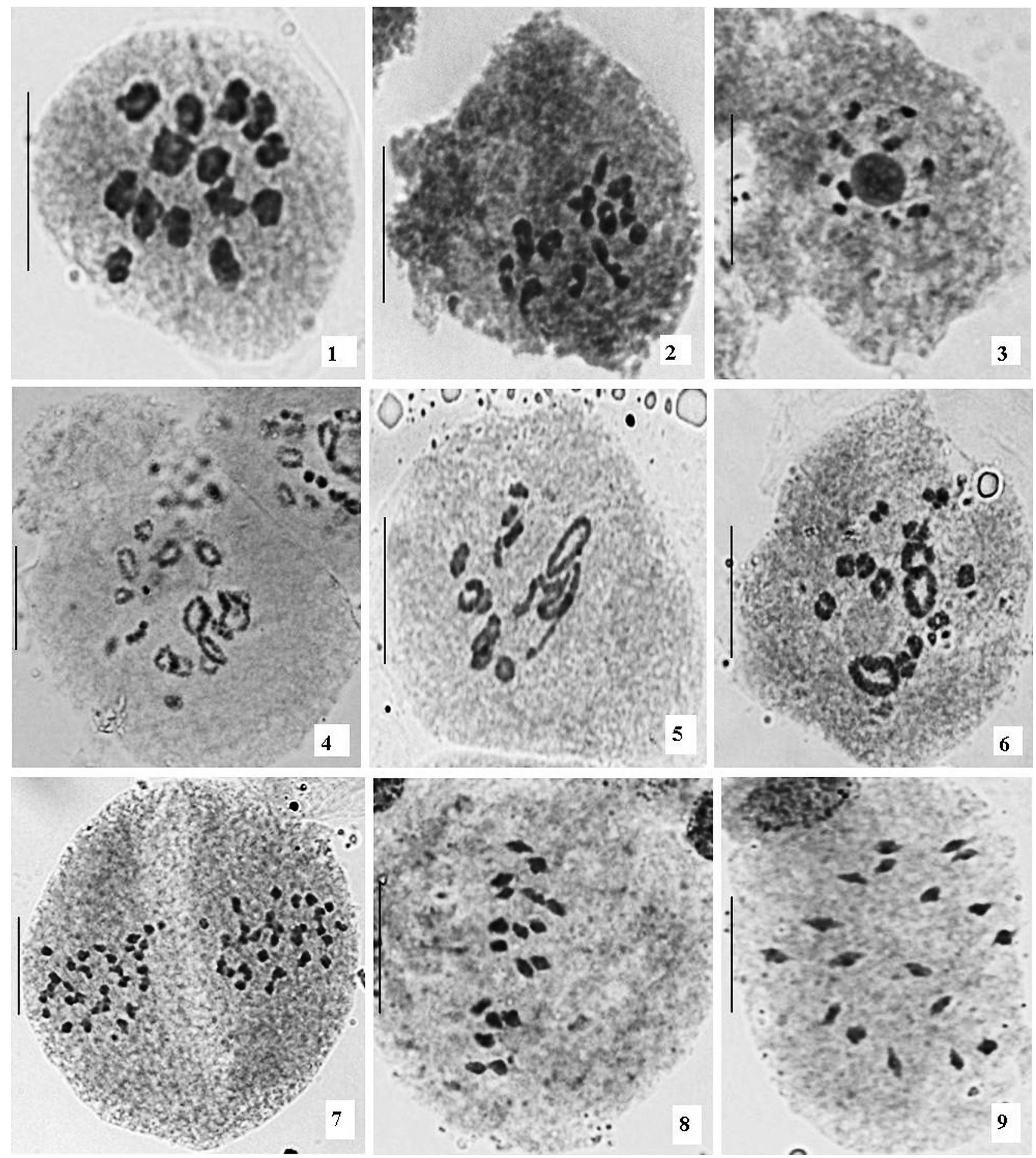

Figs. 1-9 1). Agrostis debilis, PMC at M-I (n=14); 2). Eleusine indica, PMC at M-I (n=14); 3). Piptatherum microcarpum, PMC at Diakinesis $(\mathrm{n}=12) ; 4)$. Poa annua, PMC at M-I (n=14+3B); 5). Poa nepalensis, PMC at M-I (n=14); 6). Poa setulosa, PMC at Diakinesis (n=14); 7). Rottboellia exaltata, PMC at A-I (n=30); 8). Setaria barbata, PMC at M-I (n=18); 9). Setaria megaphylla, PMC at M-I ( $=18)$. Scale $=10 \mu \mathrm{m}$

Shaw 1973). Fifty two species are reported from Indian subcontinent (Bor 1960), mostly restricted to the hills. The species worked out at present is a common weed of cultivated fields and has a dense growth in marshy places especially in cool, shady places near hedges. It grows within altitudinal range of 200-4,000 $\mathrm{m}$ in Himalayas. It is characterized as an annual winter grass; absence of web on callus and hooks on the panicle branches as well as spikelet bracts. The flowering and fruiting is seen almost throughout the year. The course of meiosis is highly abnormal and marked with cytomixis. However, the PMC's with normal meiotic course depict chromosome number as $n=14$ and varied number of B-chromosomes from 0-3B per PMC (Fig. 4). 


\section{5) Poa nepalensis Wallich ex Duthie}

At present the species is found in the altitudes ranging from $1,900 \mathrm{~m}$ to $4,000 \mathrm{~m}$ in meadows on slopes, roadsides, disturbed grounds and at lower elevations in Himachal Pradesh. $P$. nepalensis is endemic to Himalayas and occurs along its whole range. It is characterized by roots commonly $0.2-0.3 \mathrm{~mm}$ in diameter; lemma as long as wide, apex obtuse to acute; palea keels densely pilulose to villous to near apex. The flowering and fruiting is seen in the months of March-May. The course of meiosis is noted to be normal with $n=14$ (Fig. 5).

\section{6) Poa setulosa Bor.}

The presently worked out species is found to be common in shady moist places along the roadsides at Bhagsunaag between altitudes of 1,500-4,000 m. It is an endemic species of the Western Himalayas and is characterized as perennial with ligules 2.5-3 mm long; spikelets wedgeshaped; lower glume longer than the lowest lemma and anthers $0.6-0.8 \mathrm{~mm}$ long. The flowering and fruiting occurs in the months of March-May. The course of meiosis is found to be normal with $n=14$ (Fig. 6).

\section{7) Rottboellia exaltata L.f.}

The genus includes four tropical and subtropical species (Airy Shaw 1973). In Indian subcontinent, genus is represented by two species (Bor 1960). The presently worked out species is found to be common in moist places and rare in fields at Bada Gran between altitudes of 1,500 $2,500 \mathrm{~m}$. The species is characterized by a stout and erect stem; leaf sheath hispid with tubercle-based hairs; glume ovate-oblong; sessile spikelets $1 / 6$ to $1 / 5$ in.; pedicelled spikelets usually adnate by one margin to the joint, 1-2 fid. The flowering and fruiting is seen in the months of JuneSeptember. The course of meiosis is abnormal but no cytomixis seen at any stage. The PMC's with normal meiotic stages exhibit $n=30$ (Fig. 7).

8) Setaria barbata (Lamk.) Kunth.

The genus includes 140 species (Airy Shaw 1973) distributed throughout the temperate and tropical regions of the world. In Indian subcontinent, the genus is represented by 17 species (Bor 1960). The species worked out at present is found to be common on slopes and roadsides in Himachal Pradesh. It grows within altitudinal range of $600-2,500 \mathrm{~m}$ in Himalayas. The species is characterized by its annual habit; upper glume half to three quarters the length of the upper lemma; branches of the panicle divided from the base and bearing short racemes and spikelets elliptic-acute and crowded. The flowering and fruiting occurs in the months of JulyDecember. The course of meiosis is abnormal with spindle malfunctioning at various stages. The PMC's with normal meiotic behaviour exhibit $n=18$ (Fig. 8).

\section{9) Setaria megaphylla (Steud.) T. Durand \& Schinz}

The presently worked out species is found to be common in shady moist places along the roadsides between altitudes of $800-2,000 \mathrm{~m}$ in Himachal Pradesh. It is characterized by its perennial habit; spikelets less secund on branches and upper glume half as long as the upper lemma or less. The flowering and fruiting is seen in the months of JulySeptember. The course of meiosis is found to be normal with $n=18$ (Fig. 9).

\section{Conclusion}

At present more than 100 species exclusively of family Poaceae have been worked out for the first time from district Kangra of Himachal Pradesh. Out of these, the observations pertaining to five species have brought to light new chromosome number/varied chromosome number reports for the first time on world-wide basis and for four species of India basis. This information is of immense significance pending its addition to chromosomal database cataloguing of plants of India in general and Western Himalayas in particular.

ACKNOWLEDGEMENTS. The authors are grateful to the University Grants Commission, New Delhi for providing financial assistance under the DRS SAP II and ASIST. We are highly thankful to the Joint Director and Deputy Director BSI, Dehra Dun for the help in the identification of the plant species.

\section{Literature Cited}

Airy Shaw, H. K. 1973. A dictionary of Flowering plants and Ferns (Revised $8^{\text {th }}$ ed. of the late J.C. Willis), Univ. Press Cambridge.

Bor, N. L. 1960. The Grasses of Burma, Ceylon, India and Pakistan. Pergamon Press.

Fedorov, A. N. A., Ed. 1969. Chromosome numbers of flowering plants. Academy of science of the USSR Komarov Botanical Institute Leningrad (Reprint, 1974).

Kumar, V. and Subramaniam, B. 1986. Chromosome atlas of flowering plants of the Indian subcontinent, Vol.II., Monocotyledons, BSI, Calcutta.

Santapau, H. and Henry, A. N. 1973. A dictionary of the flowering plants in India. C.S.I.R., New Delhi. Purohit.

Web: Missouri Botanical Garden Tropics, Nomenclatural Date Base http://mobot.mobot.org/W3T/Search/ipcn.html accessed upto 14th January 2011. 